\title{
SISTEM INFORMASI AKADEMIK BERBASIS WEB DENGAN KONSEP HUMAN AND COMPUTER INTERACTION: STUDI KASUS STMIK DHARMA PUTRA
}

\author{
Sobiyanto ${ }^{1}$, Hari Santoso ${ }^{2}$, Jansen Wiratama ${ }^{3}$ \\ ${ }^{1,2,3}$ Program Studi Teknik Informatika,STMIK Dharma Putra \\ Jl. Ottoiskandardinata no 80 Tangerang Telp. (021) 55767065 \\ E-mail : sobi_yanto@yahoo.co.id
}

\begin{abstract}
Abstrak
Sistem Informasi Akademik pada STMIK Dharma Putra Tangerang masih menggunakan sistem Desktop. Dengan Sistem desktop terdapat kekurangan, terutama dalam hal pengolahan data. untuk pengisian Kartu Rencana Studi (KRS) dan pembagian Kartu Hasil Studi (KHS) mewajibkan mahasiswa/i harus datang untuk mengisi KRS dan mengambil KHS. Hal ini kurang efisien sebab setelah mengisi KRS subbag akademik harus menginput data KRS ke dalam Sistem Informasi Akademik berbasis desktop. Penerapan Sistem Informasi Akademik berbasis web menggunakan konsep Human and Computer Interaction sehingga aplikasi yang dihasilkan dapat digunakan (Usability). Apilkasi ini menggunakan metode pengembangan waterfall, analisis dengan pendekatan elisitasi dan pengujian kualitas sistem menggunakan Mccall's.
\end{abstract}

Kata Kunci: Sistem Informasi Akademik, Web, Human and Computer Interaction

\begin{abstract}
The Academic Information System at STMIK Dharma Putra Tangerang still uses the Desktop system. With desktop systems there are disadvantages, especially in terms of data processing. for filling out Study Plan Cards (KRS) and the distribution of Study Results Cards (KHS) requires students to come to fill in the KRS and take KHS. This is not efficient because after filling the KRS the academic sub-section must input KRS data into the desktop-based Academic Information System. The application of a web-based Academic Information System uses the concept of Human and Computer Interaction so that the resulting application can be used (Usability). This application uses the waterfall development method, analysis using the elicitation approach and system quality testing using Mccall's
\end{abstract}

Key words: Academic information system,Webbased, Human and Computer Interaction

\section{PENDAHULUAN}

\subsection{Latar Belakang}

Pendidikan sebagai pondasi yang sangat penting dalam membangun suatu bangsa yang memerlukan pembaharuan-pembaharuan sesuai dengan tuntutan dan kemajuan zaman. Perkembangan Teknologi informasi dan komunikasi (TIK) yang sangat cepat telah banyak mempengaruhi perilaku dan cara pandang manusia. Contoh yang dapat dilihat dalam kehidupan sehari-hari adalah penggunaan internet yang dapat digunakan disegala bidang salah satunya dibidang akademik dimana internet dapat berperan aktif dalam membantu proses pengisian Kartu Rencana Studi dan mengunduh Kartu Hasil Studi mahasiswa/i. 
Proses pengisian Kartu Rencana Studi dan informasi Kartu Hasil Studi di STMIK Dharma Putra masih menggunakan sistem Desktop, artinya mahasiswa/i harus datang ke STMIK Dharma Putra untuk mengambil Kartu Hasil Studi dan mengisi Kartu Rencana Studi Hal ini menjadi keluhan mahasiswa/i sebab hampir 90 persen mahasiswa/i STMIK Dharma Putra adalah pekerja. Untuk itu kebutuhan akan suatu konsep dan mekanisme dalam menyajikan pelayanan akademik, khususnya mengenai Kartu Hasil Studi dan Kartu Rencana Studi yang efektif dan interaktif berbasis teknologi dan komunikasi dapat diatasi dengan melakukan penerapan yang dinamakan Sistem KHS dan KRS berbasis web. Dan perlu diperhatikan juga dalam pembuatan sistem ini, rancangan yang digunakan berdasarkan suatu konsep Human and Computer Interaction (usability, safe, functional, effective, dan efficient) agar sistem yang dihasilkan dapat digunakan dengan mudah (User Friendly).

Penerapan Sistem pengunduhan KHS dan Pengisian KRS sendiri pun menggunakan bahasa pemograman VB.net dengan database Mysql, dengan editor dreamweaver, Metode pengembangan menggunakan tahapan waterfall, Tahapan analisis menggunakan pendekatan elisitasi, Model perancangan menggunakan UML, Desain Sistem menggunakan konsep Human and Computer Interaction dan pengujian kualitas sistem menggunakan Mccall's. Proses implementasi aplikasi Sistem pengunduhan KHS dan Pengisian KRS akan dilakukan pada jaringan internet.

\section{METODE PENELITIAN}

\subsection{Metode Pengumpulan Data}

Dalam setiap kegiatan penelitian selalu ada pengumpulan data, Hal ini merupakan salah satu tahapan sangat penting dalam penelitian. Teknik pengumpulan data yang benar akan menghasilkan data yang memiliki kredibilitas tinggi dan sebaliknya. Oleh karena itu, pengumpulan data dalam penelitian ini meliputi:

1. Studi Pustaka

Pada tahapan ini pustaka dilakukan dengan cara mengumpulkan data yang dibutuhkan sebagai bahan dalam melengkapi penelitian. Pengumpulan data dan informasi dengan cara mempelajari buku-buku yang berkaitan dengan penelitian dan referensi dari media internet sehingga dapat dijadikan sebagai acuan dalam pembahasan dalam penelitian.

2. Wawancara

Wawancara terstruktur adalah wawancara dengan menggunakan daftar pertanyaan yang telah disiapkan sebelumnya. Pertanyaan yang sama diajukan kepada semua responden, dalam kalimat dan urutan yang seragam. Wawancara yang dilakukan meliputi identifikasi faktor-faktor kebutuhan informasi tentang pengembangan Sistem Informasi Akademik di STMIK Dharma Putra Tangerang. Keuntungan dari metode ini adalah mampu memperoleh jawaban yang berkualitas.

3. Observasi

Dalam metode penelitian kuantitatif. Observasi hakikatnya merupakan kegiatan dengan menggunakan panca indera, bisa penglihatan, penciuman, pendengaran, untuk memperoleh informasi yang diperlukan untuk menjawab masalah penelitian. Hasil Observasi berupa aktifitas, kejadian, peristiwa, objek, kondisi atau suasana tertentu dan perasaan emosi seseorang. Observasi dilakukan untuk memperoleh gambaran riil suatu peristiwa atau kejadian untuk menjawab pertanyaan penelitian, yaitu:

a. Observasi Partisipasi

b. Observasi Tidak Terstruktur

c. Observasi Kelompok 
4. Kuesioner

Kuesioner adalah pertanyaan terstruktur yang diisi sendiri oleh responden atau diisi oleh pewawancara yang membacakan pertanyaan dan kemudian mencatat jawaban yang diberikan. Pertanyaan yang akan diberikan pada kuesioner ini adalah pertanyaan menyangkut fakta dan pendapat responden, sedangkan kuesioner yang digunakan pada penelitian ini adalah kuesioner tertutup, dimana responden diminta menjawab pertanyaan dengan menjawab dengan memilih dari sejumlah alternatif. Keuntungan bentuk tertutup ialah mudah diselesaikan, mudah dianalisis dan mampu memberikan jangkauan jawaban.

5. Instrumentasi

Dalam penelitian ini, instrument yang digunakan untuk mengumpulkan data adalah;

a. Instrumen untuk pengumpulan data dengan metode wawancara

Instrumen wawancara ini adalah peneliti terhadap pengembangan Sistem Informasi Akademik serta rancangan daftar pertanyaan wawancara, yang berkaitan dengan datadata tentang masalah penelitian

b. Instrumen untuk pengumpulan data dengan metode observasi

Instrumen observasi ini adalah peneliti yang melakukan pengamatan langsung di STMIK Dharma Putra Tangerang

c. Instrumen untuk pengumpulan data dengan metode studi pustaka Instrumen studi pustaka ini adalah peneliti yang mempelajari literature tentang konsep dasar pengembangan Sistem Informasi Akademik dan sumber daya manusia.

d. Instrumen untuk pengumpulan data dengan metode kuesioner/angket

Untuk mengukur konsep yang akan diteliti, maka penulis membuat suatu instrumen dalam bentuk kuesioner, dikarenakan yang akan diukur adalah persepsi atau pendapat responden, amak skala yang akan digunakan dalam penelitian ini menggunakan skala linkert.

\subsection{Teknik Analisis Sistem}

Teknik Analisis yang digunakan pada penelitian ini menggunakan pendekatan observasi dan analisis berorientasi objek dengan UML. Proses Analisis dilakukan terhadap hasil tahapan pengumpulan data dengan wawancara, observasi, dan studi pustaka untuk mendapatkan spesifikasi kebutuhan sistem yang akan dikembangkan. Pada proses analisis, teknik yang dilakukan adalah:

- Analisis data dan Informasi Sistem Berjalan. Analisis dilakukan terhadap prosedur, dokumen, file dan hasil catatan dari sistem yang sudah berjalan.

- Analisis Kebutuhan fungsional, Non-Fungsional dan pengguna.

Pemodelan kebutuhan fungsional untuk menggambarkan fungsi sistem dan pengguna yang terlibat serta fungsi-fungsi apa saja yang bisa didapatkan oleh pengguna. Untuk hal ini juga dapat dilakukan dengan proses Elisitasi yang didapat melalui proses wawancara, proses wawancara pun hanya melibatkan stakeholder disini adalah Ketua, akademik dan masukan dari para dosen STMIK Dharma Putra. Setelah diwawancara barulah didapat kebutuhan fungsionalnya untuk dilakukan proses elisitasi untuk mendapatkan requirement untuk sistem yang akan dibangun.

\subsection{Teknik Perancangan Sistem}

Teknik Perancangan sistem yang digunakan adalah dengan Metode System Development Life Cycle (SDLC) model waterfall yang akan diangkat penulis ini memiliki 4 tahapan proses diantaranya: Analisa Kebutuhan, Desain Sistem, Pengkodean Sistem dan Pengujian Sistem.Pada penelitian ini digunakan teknik perancangan dengan menggunakan pendekatan metode Object Oriented Design (OOD) atau perancangan berorientasi objek dengan menggunakan UML. 
Pada proses perancangan , teknik perancangan yang dilakukan adalah:

1. Membuat dan mengetahui secara detail Sistem Akademik yang saat ini masih berjalan.

2. Perancangan sistem bisnis proses yang baru khususnya sistem pengembangan Sistem Informasi Akademik.

3. Perancangan antarmuka pengguna dan database dalam sistem informasi akademik yang baru.

4. Perancangan Infrastructure Architecture (hardware, software, dan jaringan).

\subsection{Teknik Implemestasi Sistem}

Yang dimaksudkan dari implementasi sistem pada penelitian ini adalah implementasi berdasarkan hasil analisis dan perancangan sistem. Teknik implementasi dibagi menjadi tiga yaitu :

a. Lingkungan Implementasi. Meliputi hardware, software dan jaringan yang digunakan.

b. Implentasi Database. Implementasi database dengan menggunakan perangkat lunak database.

c. Implementasi sistem. Implementasi sistem terdiri dari implementasi sistem perekrutan, data induk, data riwayat dan laporan.

\subsection{Teknik Pengujian Sistem}

\subsubsection{Pengujian Validasi}

Pengujian validasi bertujuan melakukan penilaian apakah spesifikasi kebutuhan telah diakomodasi dalam sistem/perangkat lunak yang dikembangkan. Selain itu juga menilai apakah Sistem Informasi Akademik dapat berfungsi membantu dan mempermudah dalam penyediaan data Akademik Mahasiswa/i dalam pelayanan akademik dan meningkatkan kecepatan layanan informasi Akademik Mahasiswa/i.

Pengujian validasi menyediakan jaminan akhir bahwa perangkat lunak memenuhi semua persyaratan informasi, fungsional, perilaku dan persyaratan kinerja sebelum diserahkan ke pengguna. Pengujian validasi dalam penelitian ini dilakukan untuk menguji hipotesis pertama dalam penelitian ini.

Teknik pengujian validasi sistem dalam penelitian ini dilakukan dengan menggunakan metode Focus Group Discussion. (FGD) merupakan diskusi kelompok yang pesertanya terbatas (dipilih) menurut kriteria tertentu dan pembahasannya memfokuskan pada topik tertentu.

a. Instrumen Pengujian FGD

Peneliti menyiapkan form berisi daftar spesifikasi kebutuhan fungsional sistem yang dibangun. Fokus diskusi adalah memvalidasi kebutuhan fungsional perangkat lunak yang dikembangkan apakah telah sesuai dengan spesifikasi kebutuhan yang sudah ditentukan dalam tahapan analisis. Instrumen Rancangan Rekapitulasi Pengujian Validasi disertakan dalam Lampiran.

b. Teknik Pemilihan Informan

Kriteria pemilihan karakteristik responden sebagai informan untuk pengujian validasi ini berdasarkan kelompok pengguna yang akan menggunakan Sistem Informasi Akademik. Teknik pemilihan informan dalam FGD dilakukan dengan pemilihan informan (peserta diskusi) berdasarkan kriteria sebagai berikut:

1. Memiliki tugas dan tanggung jawab sebagai pimpinan Akademik dan Staf akademik atau mereka yang memiliki tanggung jawab atas berjalannya kegiatan Akademik.

2. Mahasiswa/i aktif STMIK Dharma Putra dari 2 (dua) program studi. 
Penelitian ini bertujuan untuk menguji apakah aplikasi Sistem Informasi Akademik sudah sesuai dengan spesifikasi kebutuhan fungsional dan berfungsi menyediakan data Akademik Mahasiswa/i terintegrasi dan meningkatkan kecepatan layanan informasi Akademik Mahasiswa/i. Oleh karena itu peneliti memilih informan untuk penelitian ini yaitu Ketua, Ketua Program Studi, Akademik, Dosen dan juga Mahasiswa/i STMIK Dharma Putra

c. Teknik Pelaksanaan FGD

Pelaksanaan Focus Group Discussion atau diskusi terfokus dalam penelitian ini dihadiri oleh peserta terpilih berdasarkan kriteria yang disebutkan sebelumnya. Pada awal FGD, peneliti melakukan presentasi dan demo aplikasi Sistem Informasi Akademik berdasarkan web based yang sudah dikembangkan dan menjelaskan setiap fungsi yang ada berdasarkan instrumen yang sudah disiapkan. Selanjutnya peserta FGD memberikan informasi, tanggapan dan persetujuan. Untuk keperluan analisis, hasil pengujian, selanjutnya peneliti membuat kesimpulan berdasarkan hasil FGD.

\subsubsection{Pengujian kualitas perangkat lunak}

Pengujian kualitas perangkat lunak dilakukan sesuai dengan metode pengembangan sistem yang digunakan, yaitu pada tahap penyerahan sistem model waterfall Pengujian sistem dilakukan untuk memvalidasi terhadap kualitas dari sistem informasi dilakukan dengan menggunakan Mccall's. Pengujian penerimaan pengguna yang dilakukan meliputi pengujian fungsionalitas dan non-fungsionalitas sistem, percepatan memperoleh informasi perusahaan, dan pengujian terhadap hasil analisis dan perancangan. Pengujian ini dilaksanakan dengan menggunakan metode kuesioner. Metode pengambilan sample dalam penelitian ini adalah purposive sampling. Pengambilan sampel dalam pengujian kecepatan sistem dilakukan dengan purposive sampling merupakan teknik pengambilan sampel dengan mengambil responden yang terpilih betul oleh peneliti menurut ciri-ciri spesifik yang dimilki oleh sampel tersebut. Adapun kriteria pemilihan responden sebagai sampel penelitian ini adalah: Mahasiswa/i yang aktif. Untuk itu Pemilihan responden sampel ini dengan pertimbangan berdasarkan keterlibatan didalam sistem.

Kualitas software diukur dengan metode Mccall's, yaitu penjumlahan dari keseluruhan kriteria dalam suatu faktor sesuai dengan bobot (weight) yang telah ditetapkan. Rumus pengukuran yang digunakan adalah:

$F a=w 1 c 1+w 2 c 2+\ldots+w n c n$

Dimana:

Fa adalah nilai total dari factor

wi adalah bobot untuk criteria

ci adalah nilai untuk criteria

Kemudian tahapan yang harus kita tempuh dalam pengukuran adalah sebagai berikut:

Tahap 1: Tentukan kriteria yang digunakan untuk mengukur suatu factor

Tahap 2: Tentukan bobot (w) dari setiap kriteria (biasanya $0<=\mathrm{w}<=1$ )

Tahap 3: Tentukan skala dari nilai kriteria (misalnya, $0<=$ nilai kriteria $<=10$ )

Tahap 4: Berikan nilai pada tiap kriteria

Tahap 5: Hitung nilai total dengan rumus $\mathrm{Fa}=\mathrm{w} 1 \mathrm{c} 1+\mathrm{w} 2 \mathrm{c} 2+\ldots+$ wncn 


\section{HASIL DAN PEMBAHASAN}

\subsection{Hasil Sistem Usulan}

Adapun hasil dari Elisitasi dalam bentuk Final Draft, sebagai berikut:

Tabel 1 Final Draft Elisitasi

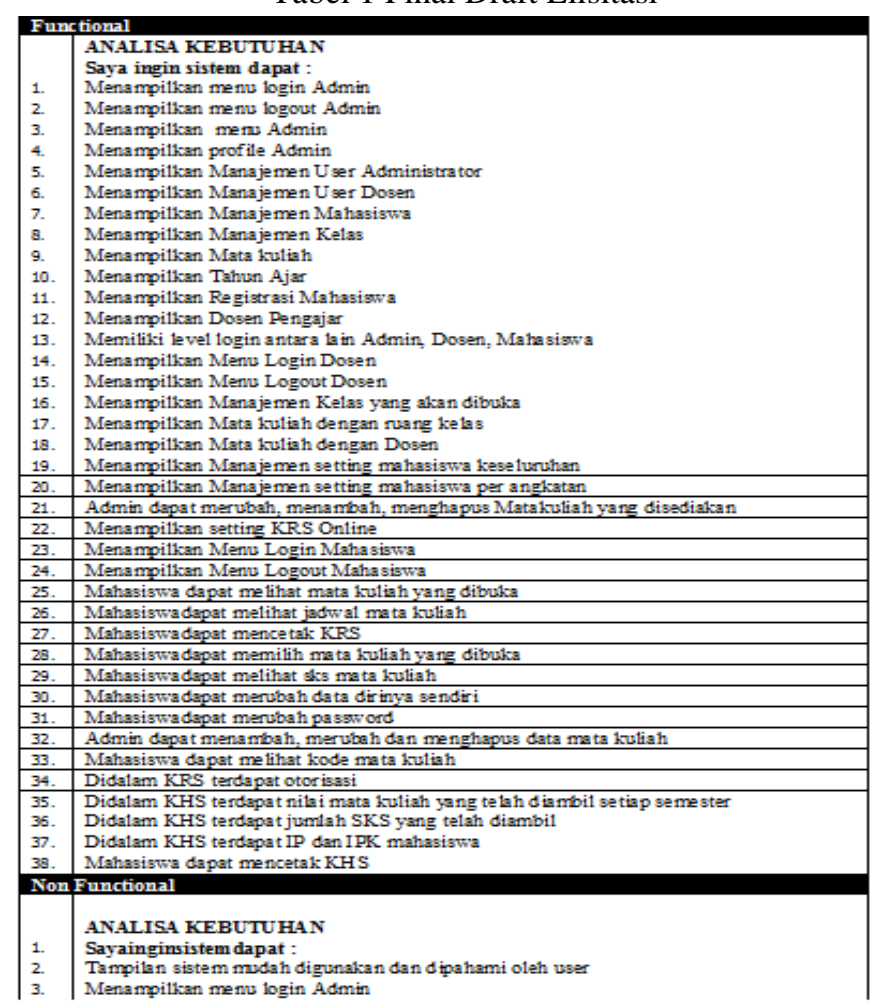

\subsection{Hasil Perancangan}

Setelah mengetahui kebutuhan sistem (user requirements) dari rangkuman wawancara yang dituangkan dalam draft elisitasi, maka langkah selanjutanya adalah membuat rancangan dengan menggunakan UML, yang terdiri dari: Use Case Diagram, Activity Diagram, Sequence Diagram dan Class Diagram.

a. Usecase

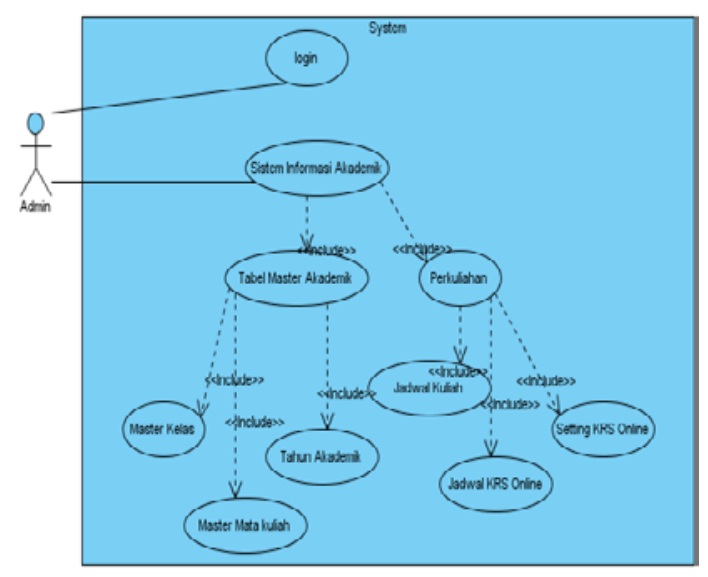

Gambar 1. Usecase Ruang Akademik

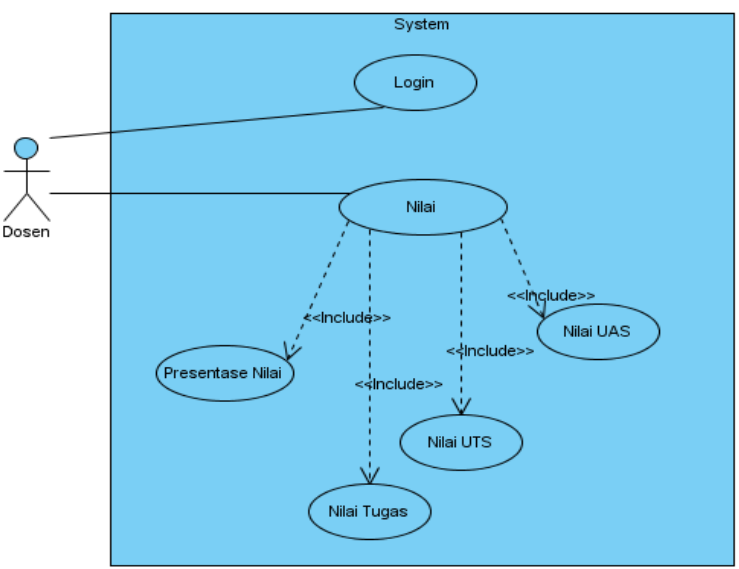

Gambar 2. Usecase Ruang Dosen 
Computatio: Journal of Computer Science and Information Systems, volume 3, no. 1, April 2019

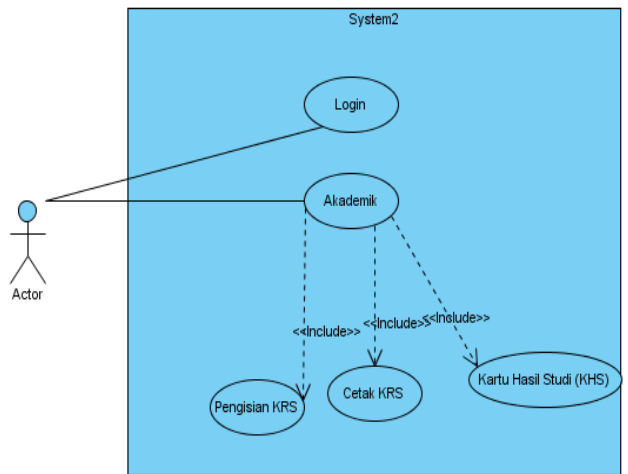

Gambar 3. Usecase Ruang Mahasiswa

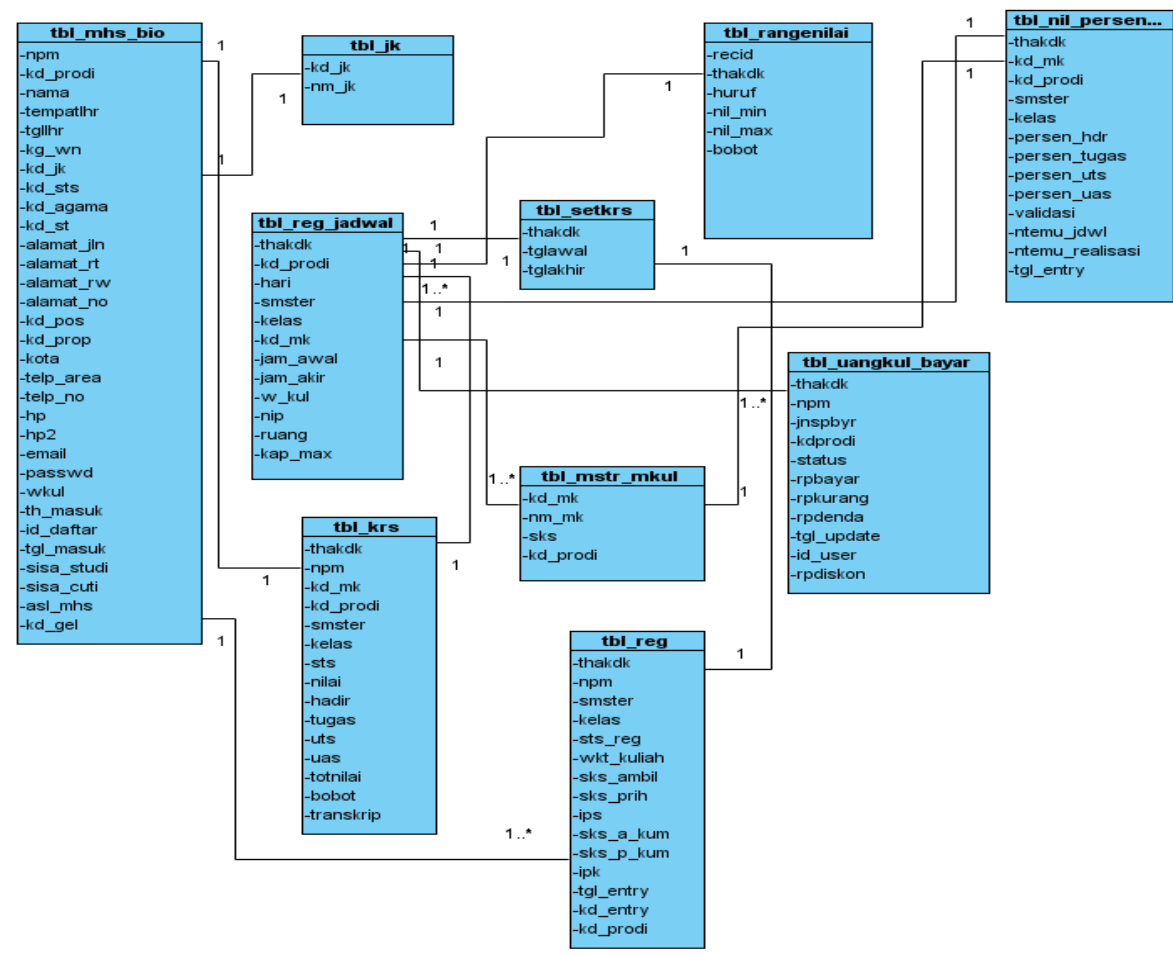

Gambar 4. Class Diagram Sistem Informasi Akademik berbasis online

3.3 Kontruksi Antar Muka

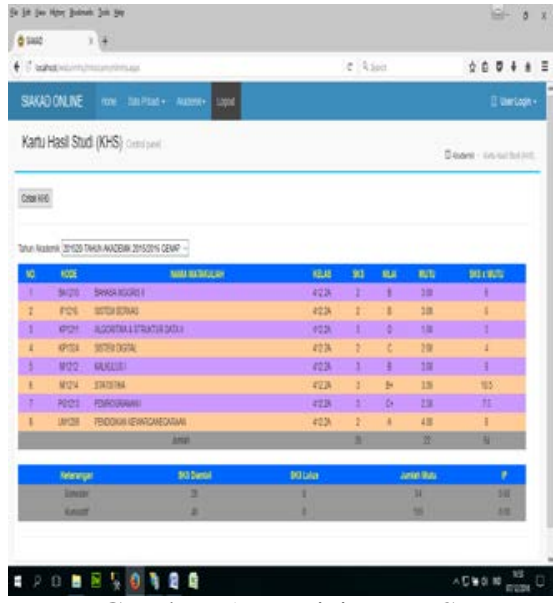

Gambar 5.Pengisian KRS 


\subsection{Pengujian Sistem}

\subsubsection{Pengujian Validasi Sistem}

Pengujian validasi sistem dilakukan dengan 2 responden, yaitu: Staf (FGD) dan Mahasiswa/i(User Acceptance).

a. Focus Group Discussion

Tabel 2. Hasil FGD

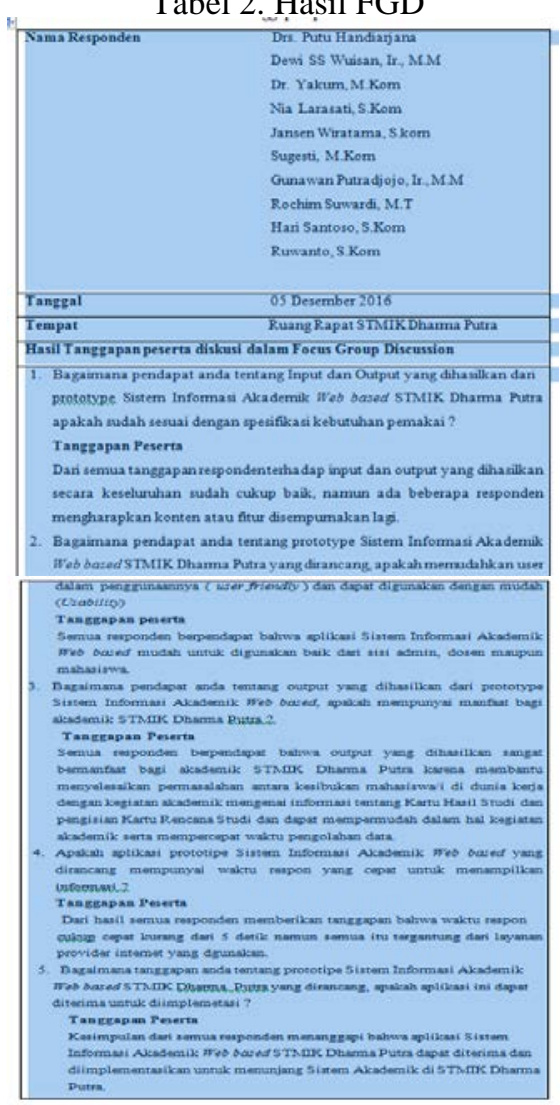

Berdasarkan hasil Focus Group Discussion yang telah dilakukan di STMIK Dharma Putra, maka dapat disimpulkan bahwa prototype aplikasi Sistem Informasi Akademik Web based menggunakan metode pengembangan sistem waterfall dengan pendekatan elisitasi sudah cukup sesuai dengan spesifikasi kebutuhan fungsional yang dibutuhkan pengguna, sehingga hipotesis dalam penelitian ini sudah terbukti. Dari hasil Focus Group Discussion diatas, seluruh reponden menyatakan bahwa prototype aplikasi Sistem Informasi Akademik Web based dapat diterima untuk diimplementasikan

\section{b. User Acceptance.}

Tabel 3. Perhitungan User Acceptance

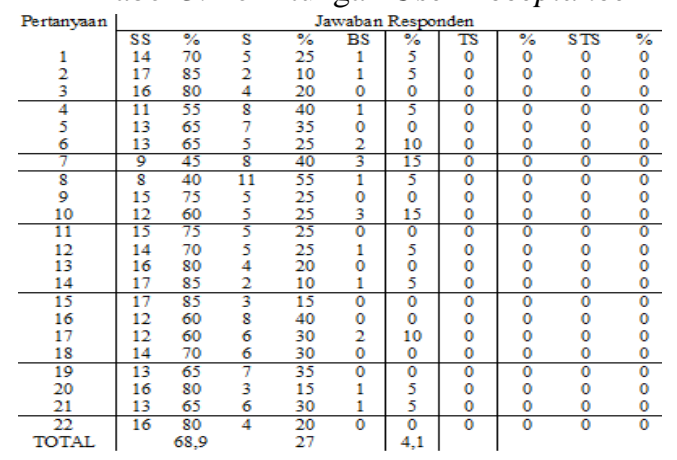


Dari hasil penilaian pengujian user acceptance test dapat diambil kesimpulan yaitu:

1. Pengguna sistem yang telah memilih Sangat Setuju (SS) mendapat nilai $68,9 \%$

2. Pengguna sistem yang telah memilih Setuju (S) mendapat nilai $27 \%$

3. Pengguna sistem yang telah memilih Biasa Saja (BS) mendapat nilai 4,1\%.

4. Pengguna sistem yang telah memilih Tidak Setuju (TS) mendapat nilai $0 \%$

5. Pengguna sistem yang telah memilih Sangat Tidak Setuju (STS) mendapat nilai 0\%

\subsubsection{Pengujian Kualitas Sistem}

Tabel 4. Perhitungan Bobot dan Nilai

\begin{tabular}{|c|c|c|c|}
\hline Faktor & Pertanyaan & Bobot & Nilai \\
\hline \multirow[t]{5}{*}{ Accessibility } & a. Waktu pencarian situs ruajar dan masuk akal. & 0,4 & 4,95 \\
\hline & b. Latar belakang situs kontras & $a, 1$ & 4,95 \\
\hline & c. Ukuran font/spasi mudah di baca & 0,2 & 4,9 \\
\hline & $\begin{array}{l}\text { d. Cahaya dan dig unakan dengan hemat dan } \\
\text { tepat }\end{array}$ & 0,1 & 4,95 \\
\hline & $\begin{array}{l}\text { e. Situs mempunyai halaman Not } \\
\text { Fouend halaman } 404\end{array}$ & 0,2 & 4,95 \\
\hline \multirow[t]{4}{*}{ Tadent iffy } & $\begin{array}{l}\text { a. Logo S TMIIK Dharma Putra bera da di tempat } \\
\text { yang mencolok }\end{array}$ & 0,2 & 4,95 \\
\hline & $\begin{array}{l}\text { b. Tagline membuat tujuan perusahaan menjadi } \\
\text { jel as }\end{array}$ & 0,2 & 4,9 \\
\hline & c. Home-page dapat dicerna dalam 5 detik & 0,2 & 4,95 \\
\hline & $\begin{array}{l}\text { d. Jalur informasi S TMIIK Dharma Putra jelas } \\
\text { e. Jalur Informasi Kontak jelas }\end{array}$ & 0,2 & $\begin{array}{l}4,95 \\
4,9\end{array}$ \\
\hline \multirow[t]{6}{*}{ Navigation } & a. Navigasi mudah di identifikasi & 0,4 & 4,95 \\
\hline & b. Labe1 Navigasi singkat dan je las & $a, 1$ & 4,9 \\
\hline & c. Jumlah tombol/ $/$ ink waj ar/masuk alal & 0,2 & 4,9 \\
\hline & d. Logo perusahaan terhubung ke homepage & 0,1 & 4,9 \\
\hline & e. Link konsisten dan mudah di identi fikasi & 0,1 & 4,9 \\
\hline & f. Situs dapat diakses dengan mudah & 0,1 & 4,95 \\
\hline \multirow[t]{4}{*}{ Content } & a. Judul utama jelas dan deskriptif & 0,3 & 4,95 \\
\hline & b. Konten kritis bagian atas terlihat & 0.2 & 4.9 \\
\hline & c. Gaya dan wama situs konsisten & 0.2 & 4.95 \\
\hline & d. Judul halaman HTMI dapat memberikan & 0.3 & 4.95 \\
\hline
\end{tabular}

Perhitungan masing-masing faktor kualitas yang dilakukan berdasarkan kriteria yang telah ditentukan adalah sebagai berikut:

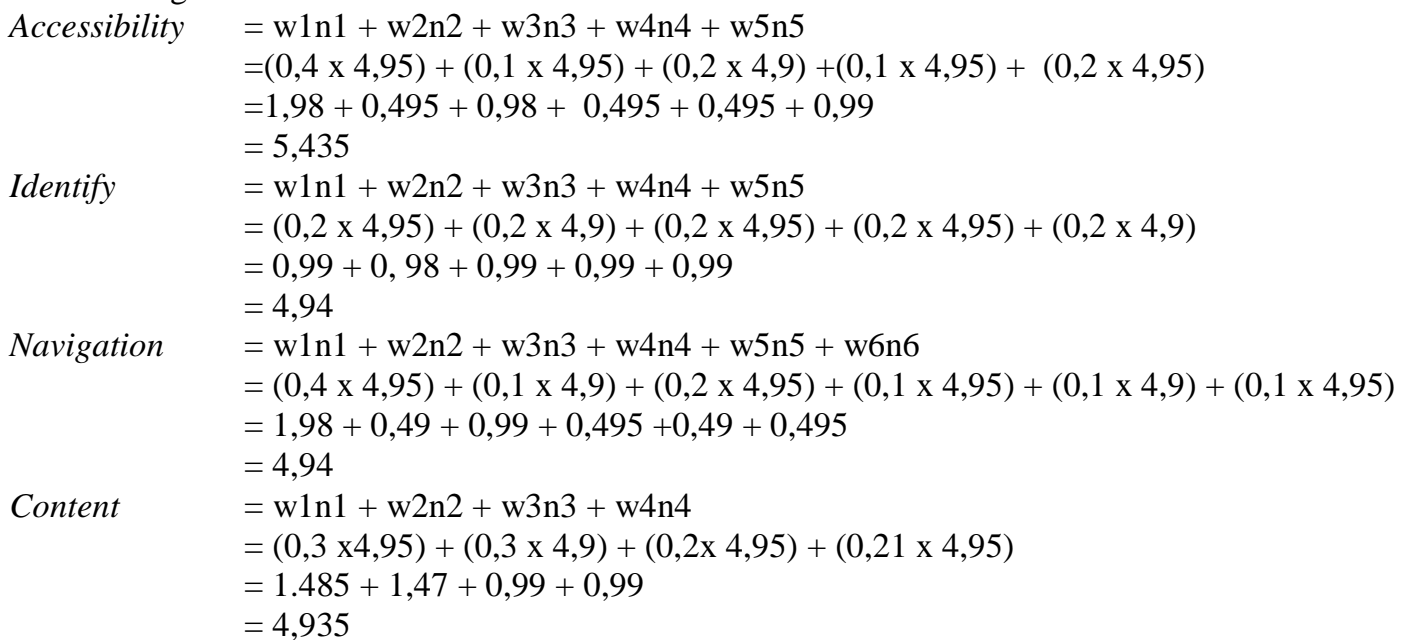

Sehingga total kualitas $\left(\sum\right.$ ) yang diperoleh adalah sebagai berikut :

$$
\begin{aligned}
\Sigma \quad & =(2 * 5,435)+(2 * 4,94)+(2 * 4,94)+(2 * 4,935) \\
& =10,87+9,89+9,89+9,87 \\
& =((40,52 * 2) / 100) * 100 \%=81,04 \% \text { (Sangat Baik) }
\end{aligned}
$$




\subsubsection{Pengujian Kecepatan Sistem}

Pengujian Kecepatan dilakukan dengan membandingkan Sistem Desktop dengan Sistem Infromasi Akademik Webbased. Adapun data yang diperoleh bahwa Sistem Informasi Akademik Webbased lebih unggul dalam kecepatan . Adapun data dapat dilihat dalam table di bawah ini:

Tabel 5. Perhitungan Kecepatan Sistem

\begin{tabular}{c|lc|c|c|c} 
No & \multicolumn{1}{|l}{ Nama/NIM } & $\begin{array}{c}\text { Waktu } \\
\text { Sistem } \\
\text { Desktop } \\
\text { (dalam menit) }\end{array}$ & $\begin{array}{r}\text { Waktu } \\
\text { Sistem SIA } \\
\text { Webbased } \\
\text { (dalam menit) }\end{array}$ & $\begin{array}{r}\text { Alat } \\
\text { Ukur }\end{array}$ & Unggul \\
\hline 1 & Sheila/111150006 & $\mathbf{1 5 9}$ & 9 & Stopwatch & Webbased \\
\hline 2 & Mencius 111150010 & 162 & 12 & Stopwatch & Webbased \\
3 & Vivi/111150025 & 166 & 10 & Stopwatch & Webbased \\
4 & Helen/111150003 & 169 & 15 & Stopwatch & Webbased \\
\hline 5 & Cindy/111150008 & 172 & 9 & Stopwatch & Webbased \\
6 & Johan/111150017 & 174 & 11 & Stopwatch & Webbased \\
7 & Corine/111150045 & 177 & 13 & Stopwatch & Webbased \\
\hline 8 & Andi/111150026 & 181 & 10 & Stopwatch & Webbased \\
9 & Sandy/111150034 & 152 & 15 & Stopwatch & Webbased \\
10 & Agnes S/111150033 & 155 & 13 & Stopwatch & Webbased \\
\hline
\end{tabular}

\section{KESIMPULAN}

Berdasarkan pada permaslahan yang muncul, kemudian dianalisis dan dibuat desain serta implementasi maka dapat diambil kesimpulan sebagai berikut:

1. Pembuatan prototipe Sistem Informasi Akademik berbasis website dengan konsep interaksi manusia dan komputer di STMIK Dharma Putra Tangerang dapat membantu menyelesaikan permasalahan antara kesibukan mahasiswa/i di dunia kerja dengan kegiatan akademik mengenai informasi tentang Kartu Hasil Studi dan pengisian Kartu Rencana Studi dan dapat mempermudah dalam hal kegiatan akademik serta mempercepat waktu pengolahan data.

2. Konsep Human and Computer Interaction dengan kriteria usability pada prototipe Sistem Informasi Akademik web based khususnya mengenai informasi Kartu Hasil Studi dan proses pengisian Kartu Rencana Studi berdasarkan web based dapat diterima dengan baik pada sistem yang dibuat. 


\section{DAFTAR PUSTAKA}

[1] Agustina, maria, 2010, Mendesain Website Dinamis dan Menarik dengan Adobe Dreamweaver CS, Andi Offset: Yogyakarta.

[2] Agus Mulyanto, 2009, Sistem Informasi Konsep dan Aplikasi, Pustaka Pelajar.

[3] Amsyah Zulkifli, 2005, Manajemen Sistem Informasi, Jakarta, Gramedia Pustaka Utama.

[4] A.S Rosa dan Shalahuddin, 2011, Modul Pembelajaran: Rekayasa Perangkat Lunak, Modula, Bandung.

[5] O'Brien, A, James, 2006, Introduction to Information System, $12^{\text {th }}$ ed, Di alih bahasakan oleh Dewi Ftriasari dan A, Kwary Deny, Jakarta: Saelmba Empat.

[6] Daniel, 2012, Analisa kebutuhan dalam rekayasa perangkat lunak. Andi Yogyakarta.

[7] Dennis, A, Wixom, B.H. \& Tegarden, 2009, D. System Analysis Design UML Version 2.0 USA: John Wiley \& Sons, Inc.

[8] Fakhreddine Karray, 2008, Mo Nours Arab Pattern Analysis and Machine Intelligent, Engineering University of Waterloo, Waterloo, Canada.

[9] Hamid Al-Jufri, 2011, Pengantar Sistem InformasiManajemen, Edisi Ke-5 Jilid 1, Bina Alumni Indonesia, Jakarta.

[10] Irwanto, 2006, Focus Group Discussion (FGD): Sebuah Pengantar Praktis, Jakarta, Yayasan Obor Indonesia.

[11] Jogianto HM, 2006, Sistem Teknologi Informasi, Andi, Yogyakarta.

[12] Juliandri, 2009, Sistem Informasi Akademik Berbasis Web di SMA Negeri 1 Dolok Batu Nanggar, USU Repository.

[13] Richard A Kruger, 2008, FOCUS GROUPS: A Practical guide for Applied Research, SAGE Publications, California.

[14] Marimin, 2010, Teori dan Aplikasi Sistem Pakar dalam Teknologi Manajerial, IPB, Bogor.

[15] Mc Leod, 2005, Sistem teknologi Informasi, Andi, Yogyakarta.

[16] Nugroho Adi, 2011, Rekayasa Perangkat Lunak Berorientasi Objek dengan Metode USDP. Andi Offset : Yogyakarta. Jakarta.

[17] O’Brein, James, 2006, Pengantar sistem informasi, Perspektif Bisnis dan manajerial, Dewi Fitriasari dan Deny A.Kwary, Penerjemah. Salemba Empat, Jakarta.

[18] Pressman, S, Roger., 2012, Software Engineering : A Practitioner's Approach, $7^{\text {th }}$ ed Di alih bahasakan oleh Adi Nugroho. J, Leopold Nikijuluw George dan et.al., yogyakarta, Andi.

[19] Robert A. Leitch dan K. Roscoe Davis, 2011, Sistem Informasi Akuntansi, Karisma Publishing Group, Tangerang.

[20] Tantra, Rudi, 2012, Manajemen Proyek Sistem Informasi Penerbit Andi, Jogyakarta.

[21] Saputro, Hendra W., 2007, Pengertian website dan unsur-unsurnya, Bandung.

[22] Tata Sutabri, 2012, Analisis Sistem Informasi, Andi, Yogyakarta.

[23] Winanti, Marliana, 2011, Sistem Informasi Akademik Berbasis Web di SMA Taman Siswa Sukabumi, Jurnal Unikom.

[24] Yunita, Renia, 2012, Sistem Informasi Akademik Pada SMA Yanita Palembang, STMIK MDP. 